\title{
Green Archives: Applications of green construction to archival facilities
}

\author{
Sarah Kim, Doctoral student, School of Information, The University of Texas at Austin
}

\section{Introduction}

The primary mission of archives as cultural and administrative institutions is to preserve and make available society's collective memories captured in archival materials for future generations. The development and long-term operation of archives in a sustainable manner are critical to accomplish this mission. Applying green or sustainable construction to archival facilities is one way to increase the sustainability of archives. Green construction methods provide various environmental, social and economic benefits to improve the serviceability of a building during its lifetime after the construction is completed at the site. ${ }^{1}$ The Building Services Research and Information Association (BSRIA) ${ }^{2}$ defines sustainable construction as "the creation and responsible management of a healthy built environment based on resource efficient and ecological principles." 3 Applying green construction to buildings means more than adding a couple of green elements to save on energy bills. Green construction reflects consideration of the impact of buildings on occupants and on the future of our global environment. Through building green archival structures, archives can respond to social concerns about climate change, global warming and harmoniously living with nature.

In November 2007, the School of Information's Kilgarlin Center for Preservation of the Cultural Record at the University of Texas at Austin hosted the From Gray Areas to Green Areas: Developing Sustainable Practices in Preservation Environments (GAGA) symposium. ${ }^{4}$ This twoday symposium aimed to examine sustainable practices in cultural heritage preservation environments. Professionals in the fields of library and information science, architecture, engineering, historic conservation, and preservation administration were invited and shared their experiences and thoughts of sustainable practices in preservation environments. This symposium opened up the floor for preservation professionals to discuss and develop "green" approaches for cultural preservation facilities. I participated in this symposium as one of the symposium organizing committee members. This study was inspired by my experience in this symposium.

In this paper, I focus on archival facilities. The purpose of this paper is to address general ideas about how to build green archives. I will review benefits as well as risks of certain types of green construction in terms of archival preservation. I will also consider how archivists can collaborate with architects, designers and engineers to apply green construction to archival facilities.

\section{Green construction for archival facilities}

Before discussing "green," it is necessary to consider the unique characteristics of archival facilities. First, archival facilities provide for collection needs. They have to support the proper preservation environment for different archival holdings, such as paper, photographs, films, digital media and so forth, with a high level of protection against fire, flooding, air 
pollution, humidity, sunlight, insects, animals, thieves, and vandalism. Second, archival facilities also have to meet the needs of people, providing the proper work environment for staff and archives' patrons. Third, the site selection, building type, and exterior and interior design of archival buildings will be dependent on types of archives. ${ }^{5}$ Each type of archives serves different types of holdings and users and has its own mission. Finally, the world of archives is changing. Archives are facing constant changes in patrons, formats of holdings, technology, quantity of holdings, and staff requirements. The design of archival buildings should be flexible and adaptable to meet these future changes. ${ }^{6}$ In general archival facilities include the following components (Table 1) and each component should satisfy its own function.

Table1. General archival facility components ${ }^{7}$

\begin{tabular}{|c|c|c|}
\hline Area & Function & Requirement \\
\hline Stacks & $\begin{array}{l}\text { Store holdings in complete safety } \\
\text { with the highest level of } \\
\text { environmental control }\end{array}$ & $\begin{array}{l}\text { - Protect holdings against fire, } \\
\text { flooding, air pollution, humidity, } \\
\text { sunlight, insects, animals, and } \\
\text { thieves }\end{array}$ \\
\hline Processing area & $\begin{array}{l}\text { Include a space for appraisal, } \\
\text { arrangement, description, housing, } \\
\text { photocopying, digitizing and so } \\
\text { forth }\end{array}$ & $\begin{array}{l}\text { - Provide a healthy, safe and } \\
\text { comfortable environment for staff } \\
\text { with processing supplies and } \\
\text { equipment } \\
\text { - Also provide proper environment } \\
\text { for holdings stored in this area for } \\
\text { processing }\end{array}$ \\
\hline $\begin{array}{l}\text { Conservation lab } \\
\text { (optional) }\end{array}$ & Repair damaged documents & $\begin{array}{l}\text { - Provide a healthy, safe, and } \\
\text { comfortable environment for staff } \\
\text { and holdings with sufficient } \\
\text { conservation treatment equipment } \\
\text { and infrastructure }\end{array}$ \\
\hline Staff area & $\begin{array}{l}\text { Include administrative offices, } \\
\text { staff meeting rooms, and a break } \\
\text { space }\end{array}$ & $\begin{array}{l}\text { - Provide a safe and comfortable } \\
\text { work environment for staff }\end{array}$ \\
\hline Public area & $\begin{array}{l}\text { Include a lobby, reading room, } \\
\text { exhibit space, reference desk, } \\
\text { reception desk, finding aids area, } \\
\text { public meeting room and/or } \\
\text { auditorium for public programs }\end{array}$ & $\begin{array}{l}\text { - Provide a safe and comfortable } \\
\text { work environment for users and staff } \\
\text { - Support proper environment and } \\
\text { security for holdings in reading } \\
\text { room and exhibit space }\end{array}$ \\
\hline
\end{tabular}

Although the general environmental, social and economic benefits of green construction have been widely discussed by architects and engineers, ${ }^{8}$ archivists need to consider what kinds of green construction would be suitable and applicable for archives regarding the unique figure of archival facilities as mentioned above. Benefits as well as risks of certain green construction methods should be addressed. Risks should be minimized. The following table (Table 2) shows 
examples of green construction methods and their benefits for and risks to archival facilities in general. ${ }^{9}$

Table 2. Examples of green construction methods for archival facilities

\begin{tabular}{|c|c|c|}
\hline Green construction methods & Benefits for archives & Risks to archives \\
\hline $\begin{array}{l}\text { Utilize renewable energy } \\
\text { resources } \\
\text { (Solar/Wind/Hydro/ } \\
\text { Biomass energy) }\end{array}$ & $\begin{array}{l}\text { - Save on energy bills } \\
\text { - Support sustainable energy } \\
\text { supply, especially for } \\
\text { increasing demand for } \\
\text { electronic equipment in } \\
\text { archival facilities }\end{array}$ & $\begin{array}{l}\text { Wind and hydro power may } \\
\text { be suited to only a few } \\
\text { locations. }\end{array}$ \\
\hline $\begin{array}{l}\text { Utilize natural daylight for } \\
\text { office and lobby areas }\end{array}$ & - Save on energy bills & $\begin{array}{l}\text { - Can cause UV exposure to } \\
\text { holdings } \\
\text { (In general, exterior windows } \\
\text { are not recommended in } \\
\text { storage, exhibit areas, and } \\
\text { reading rooms due to UV } \\
\text { exposure to holdings and } \\
\text { security concerns. Exterior } \\
\text { windows should not open, be } \\
\text { as small as possible, and use } \\
\text { double glazing to reduce heat } \\
\text { gain or loss through } \\
\text { windows.) }\end{array}$ \\
\hline $\begin{array}{l}\text { Use automatic lighting } \\
\text { controls }\end{array}$ & $\begin{array}{l}\text { - Save on energy bills } \\
\text { - Reduce unnecessary light } \\
\text { exposure to holdings }\end{array}$ & $\begin{array}{l}\text { - Greater initial cost of } \\
\text { construction }\end{array}$ \\
\hline $\begin{array}{l}\text { Use organic building } \\
\text { materials }\end{array}$ & $\begin{array}{l}\text { - Provide healthier work } \\
\text { environment for staff and } \\
\text { users }\end{array}$ & \multirow{2}{*}{$\begin{array}{l}\text { - Even though they are } \\
\text { organic and/or renewable, } \\
\text { some building and finishing } \\
\text { materials can release dust and } \\
\text { gas that can damage holdings. } \\
\text { (The National Archives and } \\
\text { Records Administration } \\
\text { provides information about } \\
\text { materials that should be } \\
\text { avoided in archival buildings } \\
\text { due to the potential to } \\
\text { damage holdings. }{ }^{10} \text { ) }\end{array}$} \\
\hline $\begin{array}{l}\text { Use renewable construction } \\
\text { materials }\end{array}$ & $\begin{array}{l}\text { - Less direct benefit for } \\
\text { archives, but will be helpful to } \\
\text { reduce solid waste disposal } \\
\text { fees }\end{array}$ & \\
\hline $\begin{array}{l}\text { Utilize natural air } \\
\text { conditioning }\end{array}$ & $\begin{array}{l}\text { - Save on energy bills } \\
\text { - Can prevent damage in case } \\
\text { of technological failure of high } \\
\text { tech climate control system. }\end{array}$ & $\begin{array}{l}\text { - Can bring air pollutant and } \\
\text { humidity from outside. } \\
\text { - Can cause regular } \\
\text { significant changes in }\end{array}$ \\
\hline
\end{tabular}




\begin{tabular}{|c|c|c|}
\hline & & humidity levels \\
\hline Berm against the building & $\begin{array}{l}\text { - Reduce gain and loss of heat } \\
\text { - Support sustainable } \\
\text { temperature control }\end{array}$ & $\begin{array}{l}\text { - Can cause water leaks } \\
\text { - Can increase humidity }\end{array}$ \\
\hline $\begin{array}{l}\text { Plant trees around the } \\
\text { building }\end{array}$ & $\begin{array}{l}\text { - Can help reduce gain of heat } \\
\text { by mitigating urban heat } \\
\text { island effects }\end{array}$ & \multirow[t]{2}{*}{$\begin{array}{l}\text { - Can cause insects and } \\
\text { animal problems }\end{array}$} \\
\hline $\begin{array}{l}\text { Plant local, drought resistant } \\
\text { and pest resistant plants in } \\
\text { the landscaping }\end{array}$ & $\begin{array}{l}\text { - Reduce water consumption } \\
\text { and toxic insect control } \\
\text { material } \\
\text { - Can help reduce heat gain by } \\
\text { mitigating urban heat island } \\
\text { effects }\end{array}$ & \\
\hline Use a green roof & $\begin{array}{l}\text { - Reduce heat gain through a } \\
\text { roof } \\
\text { - Can be helpful for fire } \\
\text { suppression }\end{array}$ & $\begin{array}{l}\text { - Can cause roof leakage, roof } \\
\text { collapse, insects, animal, and } \\
\text { fungi problems } \\
\text { (Since temperature and } \\
\text { humidity changes can cause } \\
\text { damage to holdings, the } \\
\text { function of a roof as barrier } \\
\text { against heat and moisture is } \\
\text { important for archival } \\
\text { facility. Also, careful } \\
\text { calculation is required } \\
\text { regarding the weight of the } \\
\text { structure, holdings, shelving, } \\
\text { and equipment.) }\end{array}$ \\
\hline $\begin{array}{l}\text { Use of a storm water } \\
\text { management and rainwater } \\
\text { catchment system }\end{array}$ & $\begin{array}{l}\text { - Reduce storm water utility } \\
\text { fees } \\
\text { - Support sustainable water } \\
\text { supply } \\
\text { - Can be helpful for fire } \\
\text { suppression }\end{array}$ & $\begin{array}{l}\text { - Can cause water leaking } \\
\text { problem especially for an } \\
\text { underground level of an } \\
\text { archival facility }\end{array}$ \\
\hline
\end{tabular}

Examples of green construction methods suggested in the above table are categories of green construction rather than specific designs or techniques that can be applied on the actual construction site. For example, there are various green techniques to utilize renewable energy resources such as installation of a passive solar or active solar system. Smart glass that responds actively or passively to environmental variables such as room temperature and daylight can be chosen among other techniques that maximize energy efficiency. ${ }^{11}$ As technology is developed and social demands increase, diverse cutting edge sustainable approaches to improve the green elements of buildings are under examination. Moreover, green construction does not necessarily rely on high-tech methods only. Low-tech approaches need to be under consideration as well. ${ }^{12}$ 
There are historical buildings that successfully adopted natural environmental control systems. For example, the triple-layer wall design, good building materials, and well planned window placement used in the new Cologne City Archives building in Germany increased natural airconditioning in the stack areas. These techniques were borrowed from the old building in where Cologne's paper records were kept from the $15^{\text {th }}$ Century to the $19^{\text {th }}$ Century. ${ }^{13}$ Helen Sheton provided briefly some examples of low-tech methods to keep environmental conditions stable in libraries and archives: the achievement of the Imperial Palace Archives in the center of Tokyo in keeping relative humidity stable by lining the walls with cedar wood planks, butt-jointed along the walls and the use of land mass around the building as thermal inertia in the Library and Archives Canada Gatineau Preservation Canter building in Ottawa. ${ }^{14}$

Benefits and risks of a certain green construction method for archival facilities can be widely different according to the financial situation, the outdoor climate and environmental setting, the unique characteristics of archival holdings, and the mission of individual archives. While there is no single answer nor one way to decide which green construction technique is appropriate for archival buildings, proper green methods can be sought and applied with a great deal of flexibility on a case by case basis.

\section{Applications of green construction to archival facilities}

\section{Collaborations}

Applying green construction to buildings does not simply mean using advanced construction technology. It should be related to the overall design of a building in which the daily social activities of occupants and the outdoor environment of the building site should be reflected. It is also related to administrative issues, issues of available resources and technological capability (high-tech and/or low-tech), and the long term serviceability of a building. Thus a successful application of green construction to archival facilities can only be achieved through a high level of collaboration between archivists, architects, designers, and engineers at an early stage of architectural design and planning of the archival facility. In this collaboration, rather than trying to obtain professional knowledge about green construction techniques, archivists need actively to address the needs of all occupants of archival facilities, which are archival collections, staff, and patrons. The role of archivists may include:

1. Understanding collection needs, people needs, the social function and mission of their archives, and the landscape and outdoor climate condition of the site;

2. Developing a statement or a general idea about the overall purpose and/or priority of applying green construction to their archival facilities (i.e. enhancing the natural environment, increasing energy efficiency, minimizing non-renewable resources consumption and so forth);

3. Providing and explaining sufficient information about archives' needs to architects, designers, and engineers including the general required building component of archival facilities;

4. Brief research on available green construction methods to open up the discussion with architects, designers, and engineers (i.e. examples suggested in Table 2); 
5. Carefully calculating (long-term) benefits and risks of possible green construction methods for their own archival facilities in their discussion with architects, designers and engineers;

6. Actively participating in the building design and planning process to maximize benefits and minimize risks of chosen green construction methods.

\section{Sharing experiences}

While green museum and library building cases are available through the Internet, ${ }^{15}$ it is hard to find reported examples of contemporary green archival facilities. This does not mean that the archival profession has not taken environmental matters seriously. This might show that there is no open channel available for archivists to share their experiences about building green archives. This lack of reported cases of green archival facilities does not help archivists actively understand the importance of the issue of being green. This also implies that the archivist who wants to apply green construction to his/her own archival facility has to gather the necessary information and knowledge from ground zero. Since actual green archives projects will require a localized approach based on special needs and the environmental conditions of a given archives facility, the importance of sharing experience, knowledge and information among archivists through specific case studies of green archives building projects is high.

\section{Conclusion}

While the term "sustainability" is interchangeable with the word "green" and their use in the literature depends on the context and the audience, ${ }^{16}$ many organizations that advocate for sustainable development define sustainability as meeting the needs of today without compromising the ability of future generations to meet their needs. ${ }^{17}$ Sustainable development starts with the long-term care and sincere understanding about people, society, and the natural environment. Increasing the sustainability of archival facilities through the application of green construction can be a win-win solution to "promote not only the conservation of our material culture, but also the conservation of our global environment" as the GAGA symposium keynote speaker, Michael Henry pointed out. ${ }^{18}$

In this paper I suggested types of green construction that can be applied to archival facilities, including their benefits and risks regarding the unique figure of archival facilities. I also pointed out that applying green construction to particular archival facilities in real building projects requires careful understanding about the needs of archival holdings, people and the outside environment at the site as well as benefits and risks of a certain green construction method. Therefore building green archives cannot be achieved by the effort of individual archivists, but in the collaboration between archivists, architects, designers and engineers. To participate actively in this collaborative effort, sharing experience and information among archivists through combined case studies of green archives building projects is necessary.

\footnotetext{
${ }^{1}$ Richard C. Hill and Paul A. Bowen, "Sustainable construction: Principles and a framework for attainment," Construction Management and Economics 15, no. 3 (1997): 237.
} 
${ }^{2}$ Building Services Research and Information Association (BSRIA) is a consultancy and research organization for construction industries based in the United Kingdom.

${ }^{3}$ Tom Woolley and others, Green Building Handbook: A Guide to Building Products and Their Impact on the Environment (London: E \& FN Spon, 1997), 5.

${ }^{4}$ From Gray Areas and Green Areas: Developing Sustainable Practices in Preservation Environments, http://www.ischool.utexas.edu/ gaga/. The symposium proceedings will be published and available through the symposium website soon.

${ }^{5}$ Types of archives include government (federal, state, and local) archives, academic archives (colleges and records of universities), collecting archives (historical societies and cultural institutions), and organizational archives (businesses, corporations, and religious archives).

${ }^{6}$ Thomas P. Wilsted, Planning New and Remodeled: Archival Facilities (Chicago: Society of American Archivists, 2007), 1-9.

${ }^{7}$ Michel Duchein, Archive Buildings and Equipment (Munchen: Verlag Dokumentation, 1977); Christopher Kitching, Archives Buildings in the United Kingdom, 1977-1992 (London: HMSO, 1993); Archives Ted Ling, Solid, Safe and Secure: Building Archives Repositories in Australia (Canberra: National Archives of Australia, 1998); Thomas P. Wilsted, Planning New and Remodeled: Archival Facilities (Chicago: Society of American Archivists, 2007).

${ }^{8}$ There is a considerable amount of literature about sustainable and green architectural methods. The following recourses were helpful to obtain general ideas about this topic; Peter Buchanan, Ten Shades of Green: Architecture and the Natural World (New York: Architectural League of New York, 2005); Brian Edward, Green Buildings Pay. (New York: Spon Press, 2004); Colin Porteous, The New Eco-Architecture: Alternatives from the Modern Movement. (New York: Spon Press, 2002); Kremers, J. A. (1995). "Defining sustainable architecture. Architronic, 4(3). Retrieved May 12, 2007, from http://architronic.saed.kent.edu/n3/n3.02a.html; Norton, J. (1995). Sustainable architecture: A definition. Habitat Debate, 5(2), 10. Retrieved May 12, 2007, from http://www.housingfinance.org/;

${ }^{9}$ I first gathered information about types of green construction from literatures in architecture. I considered the possible benefits of each type of green construction for archival facilities while reviewing general advantages of them discussed in the architecture and engineering fields. Risks addressed in this table reflect the possible harm of each type of green construction to archival facilities, regarding the particular architectural requirements for archival facilities as well as general disadvantages discussed in the architecture and engineering fields.

${ }^{10}$ Wilsted, ibid., 17.

${ }^{11}$ Peter F. Smith, Sustainability at the Cutting Edge: Emerging Technologies for Low Energy Buildings (Oxford: Architectural Press, 2003). 
${ }^{12}$ In his presentation at From Gray Areas and Green Areas: Developing Sustainable Practices in Preservation Environments symposium, Joachim Huber critically reviewed the main trend of $20^{\text {th }}$ century that riles on highly sophisticated constructions and massive use of technology for the climate control in museums and archives while comparing them with the traditional building technology that was simple but more sustainable. The abstract of Joachim Huber's presentation, "Sustainability means less is more," can be found at http://www.ischool.utexas.edu/kilgarlin/gaga/abstract.html\#Fri2-4

${ }^{13}$ Sandra Rowoldt, "The Greening of Archive Buildings: Natural Air-conditioning in the Southern African Countries," Janus 2 (1993): 36-42; Hugo Stehkamper, "Natural Air Conditioning of Stacks," Resturator 9 (1988): 163-177.

${ }^{14}$ Helen Shenton, "Strategic Developments in Collections Storage of Libraries and Archives: Architectural, Technical, Political," Liber Quarterly 15 (2005): 3-4.

${ }^{15}$ As an example, the Green Libraries website serves as a resource for creating more environmental friendly and sustainable libraries. This website provides the list of green libraries and information focusing on green library designs, green librarians, green buildings and green library organizations. The website URL is http://www.greenlibraries.org/. Greenexbihits.org provides museum exhibit designers "a resource for designing and building exhibits and environments that best support healthy spaces and a healthier future for kids and the environment." This website also contains case studies of green museum buildings. The website URL is http://www.greenexhibits.org/intro.shtml. Green Library Wikipedia page also provides a useful overview on sustainable libraries, available at http://en.wikipedia.org/wiki/Green_library.

${ }^{16}$ Woolley, Green Building Handbook, 5.

${ }^{17}$ Sustainable Philadelphia, What's sustainability?, http://www.sustainablephiladelphia.com/html/whatis.html.

${ }^{18}$ Michael C. Henry, "From the Outside In: Preventive Conservation Sustainability, and Environmental Management," The Getty Conservation Institute Newsletter 22, no. 1 (2007): 4. 